ment and is the oldest in Europe, having been founded in 1846, will be reopened to the public for the first time at the meeting of the Congress. At the close of the session, an excursion will be made through Denmark, on which visits will be paid to kitchen. middens, Megalithic tombs, tumuli of the bronze age, iron age fortifications, the new Viking ship recently discovered at Ladby, and other antiquities of the Middle Ages. Subscriptions (members 30 Danish crowns, associates $15 \mathrm{Kr}$.) may be addressed to the Treasurer of the Congress, Nationalmuseet, $10 \mathrm{Ny}$ Vestergade, Copenhagen, $\mathrm{K}$.

\section{Seventeenth International Geological Congress}

THE seventeenth International Geological Congress is being held in Moscow on July 20-30, as noted in Nature of January 23, p. 143. Many tours for the delegates have been arranged ; for this purpose guidebooks have been prepared giving detailed descriptions of the routes, all the interesting outerops of mineral strata, the deposits of useful minerals, etc., with maps, plans and sectional drawings. Every delegate has a set of twenty-eight guide-books, and a newly issued geological map of the Soviet Union; each tour is being conducted by a Soviet geologist. According to a report issued by the Soviet Union Year Book Press Service, 403 foreign delegates, representing forty-six different countries, are attending the Congress; they include 139 from the United States, 50 from Great Britain, 33 from France, 20 from Japan and Manchukuo, 13 each from Germany and South Africa, and 11 from Sweden. Of Soviet geologists, 1,600 have intimated their desire to be present, but as many of them are at present engaged in field work, not all of them will be able to attend. The delegates will spend two days in Leningrad, where a session of the Congress will be held, and visits will be paid to the geological museums of the Mining Institute, the Central Institute of Scientific Research, the Arctic Institute, to give representatives of foreign countries an opportunity of becoming acquainted with the general characteristics of the mineral resources of the Soviet Union. In Moscow, the Congress will hold its sessions at the Observatory, where the institutes of the Academy of Sciences of the U.S.S.R. have also arranged an exhibition of collections relating to mineralogy, geochemistry and useful minerals; and the Palæontological Institute is showing its collection of Perm vertebrates of the North Dvina Gallery. Among the subjects coming up for discussion at the Congress are: problems of oil and world oil resources ; geology of coal deposits ; the Pre-Cambrian system and its useful minerals; the Perm system and its stratigraphical arrangement; the inter-connexion of tectonic processes, magmatic formations and ore deposits; tectonic and geochemical problems of Asia ; deposits of rare elements ; geophysical methods in geology; geology of the Arctic and Antarctic.

\section{Beit Fellowships for Scientific Research}

The Trustees have awarded Beit fellowships for scientific research, tenable at the Imperial College of
Science and Technology during the academic year 1937-38, as follows : extensions of fellowships already satisfactorily held for one year to Dr. N. Kemmer, for the continuation of his work on the theoretical studies in nuclear physics, under the direction of Prof. S. Chapman; and to E. K. Woodford, for the continuation of his research in plant physiology, the work to be done under the supervision of Prof. F. G. Gregory ; new fellowships tenable for one year, but renewable for a second, to $\mathrm{D}$. W. Goodall, for research on the physiology of the tomato plant, under the direction of Prof. F. G. Gregory ; H. A. C. McKay, for an investigation of chemical problems by the radioactive indicator method, under the direction of Prof. J. C. Philip; A. K. Powell, for research on the various strains of Heterodera Schachtii, under the direction of Prof. J. W. Munro. The Trustees have also awarded a special Beit research scholarship to Dr. A. G. Gaydon, for research in spectroscopy under the direction of Prof. G. P. Thomson.

\section{Announcements}

Geheimrat Prof. Erich Lexer, professor of surgery in the University of Munich, and the chief representative of plastic surgery in Germany, has been awarded the Goethe Medal for art and science on the occasion of his seventieth birthday.

THE sixth International Montessori Congress will be held in Copenhagen under the auspices of the Danish Minister of Education on August 1-10. Dr. Maria Montessori will give an address entitled "Educate for Peace". Further information can be obtained from the General Director, International Montessori Association, 1 Hampstead Hill Gardens, London, N.W.3.

Accordrng to official reports, the birth-rate in Soviet Russia is steadily increasing. Last January, the number of births registered was $21 \cdot 7$ per cent higher than in January 1936, and in the first quarter of this year it was about 30 per cent higher than in the corresponding quarter of 1936. Of the Union republies the Ukraine records the largest increase for the quarter, namely, 70 per cent.

The University of Reading proposes to reprint, in type similar to that of the original and accompanied by wood-cuts of the original drawings, the "Observa. tories Anatomicæ Selectiores Amstelodamensium", 1667-73. This work, the record of the observations of the Amsterdam School on the anatomy of seven mammals, four birds, the tortoise, the frog and thir. teen fishes, is rare and its contents not widely known among biologists. Prof. F. J. Cole, to whom subscriptions for copies ( 1 guinea each) should be sent, is contributing a critical introduction.

Erratum.-In the announcement in Nature of July 17, p. 104, of the award of the Johannes Schmidt Medal to Mr. H. G. Maurice the words 'thirteenth annual meeting' should have been 'thirtieth annual meeting'. 